\title{
PRELIMINARY STUDY OF FAVORABILITY FOR URANIUM RESOURCES IN JUAB COUNTY, UTAH
}

BENDIX FIELD ENGINEERING CORPORATION Grand Junction Operations Grand Junction, Colorado 81501

February 1978

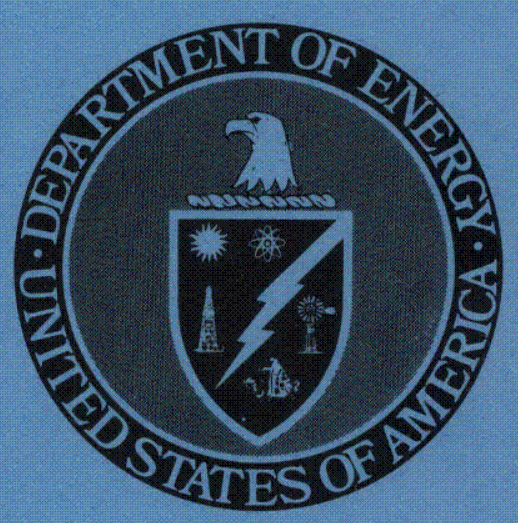

PREPARED FOR THE U.S. DEPARTMENT OF ENERGY GRAND JUNCTION OFFICE UNDER CONTRACT NO. EY-76-C-13-1664 
This report was prepared as an account of work sponsored by the United States Government. Neither the United States nor the United States Department of Energy, nor any of their employees, nor any of their contractors, subcontractors, or their employees, makes any warranty, expressed or implied, or assumes any legal liability or responsibility for the accuracy, completeness or usefulness of any information, apparatus, product or process disclosed, or represents that its use would not infringe privately owned rights. 
PRELIMINARY STUDY OF FAVORABILITY

FOR URANIUM RESOURCES IN JUAB COUNTY, UTAH

S. H. Leedom and T. P. Mitchell

\section{BENDIX FIELD ENGINEERING CORPORATION \\ Grand Junction Operations \\ Grand Junction, Colorado 81501}

February 1978

PREPARED FOR THE U.S. DEPARTMENT OF ENERGY GRAND JUNCTION OFFICE

UNDER CONTRACT NO. EY-76-C-13-1664 



\section{CONTENTS}

$\underline{\text { Page }}$

Summary . . . . . . . . . . . . . . . . . . . 1

Introduction . . . . . . . . . . . . . . . . . . . . . 2

Purpose . . . . . . . . . . . . . . . . . . 2

Location . . . . . . . . . . . . . . . . 2

Previous work . . . . . . . . . . . . . . . . 2

Procedures . . . . . . . . . . . . . . . . . . 2

Field Investigations . . . . . . . . . . . . . 2

Sample analysis................... 4

Geology . . . . . . . . . . . . . . . . . . . . 4

General stratigraphy .................. 4

Tertiary geology . . . . . . . . . . . . . . 4

Structure . . . . . . . . . . . . . . . . 6

Uranium favorability . . . . . . . . . . . . . . . 8

Hypogene deposits.... . . . . . . . . . . . 8

Dolomite rocks................... 8

Granitic rocks and pegmatite dikes........... . 9

Hydrothermally altered vitric tuffs (beryllium-

bearing tuffs)................. 9

Tufa mounds .................... . 11

Supergene deposits . . . . . . . . . . . . . . . 12

Tuffaceous sandstone . . . . . . . . . . . 12

Vitric tuffs and rhyolite flows (upper portion)..... . 13

Arkosic sedimentary rocks ............. 13

Conclusions ........................ 13 
CONTENTS (continued)

$\underline{\text { Page }}$

Blbliography . . . . . . . . . . . . . . . . . 15

Appendix A. Locations and lithologics of samples........ . 19

Appendix B. Analytical data . . . . . . . . . . . . 21 


\section{ILLUSTRATIONS}

$\underline{\text { Page }}$

Figure 1. Mineral occurrences within the west-central Utah beryllium belt . . . . . . . . 3

2. Simplified stratigraphic section, Juab County, Utah . . . . . . . . . . . . . . . 5

3. Correlation chart for stratigraphic sections in Juab County, Utah . . . . . . . . . . . . . 7

4. Favorable areas for uranium deposits in berylliumbearing tuffs ................ 10

Plate 1. Geologic map and cross section of Juab County, Utah . . . . . . . . . . . . . . In pocket

2. Sample sites, radioactivity anomalies, and beryllium occurrences . . . . . . . . . . . In pocket 

Uranium is found in a variety of geologic environments within the beryllium belt in Juab County, Utah. Large, low-grade uranium deposits are found in hydrothermally altered vitric tuffs of Pliocene(?) age. One small, medium-grade commercial uranium deposit is in tuffaceous sandstone. Fluorite vein, pipe, and replacement deposits in dolomite rocks of Middle Cambrian to Middle Devonian age contain uranium mineralization. Minor vein occurrences are found in granitic bodies of oligocene age and in vitric tuffs and rhyolite flows of Pliocene age. Uranium is also found in a pegmatite dike that intrudes schist and quartzite rocks of Precambrian age, and in tufa deposits at hot springs.

Late-stage differentiation of the parent magma, which was responsible for Miocene(?)-Pliocene volcanism, concentrated beryllium, fluorite and uranium. Low-temperature hydrothermal solutions from this magma deposited these elements in devitrified montmorillonite clays and detrital carbonate clasts within vitric tuffs, in coarse fractions of tuffaceous sandstones, and in other minor susceptible host rocks.

Major fault and fracture systems controlled emplacement of the vein deposits. Down-dropped blocks within these systems formed topographic lows that acted as depositional basins for the vitric tuffs. Hydrothermal solutions were later channeled into the tuffs and tuffaceous sands along these faults and fractures. Periodic rejuvenation of faulting has exposed these rock units at the surface and probably offset parts of the known uranium deposits.

A good possibility exists for large, low-grade uranium deposits in the vitric tuffs of Miocene(?) age. The uranium-bearing altered tuffs at Spor Mountain are exposed in Dugway Dell and probably discontinuously underlie an area of $120 \mathrm{sq} \mathrm{mi}$. Similar altered tuffs at the Honeycomb Hills do not extend much farther than the exposed outcrop.

The probability of finding other small, medium-grade uranium deposits, such as the one at the Yellow Chief mine in the Thomas Range area, is low. The structural framework, stratigraphic setting, and 1ithologic character of this deposit are unique to the Dugway Dell area and probably do not exist elsewhere in Juab County.

Vein deposits in granitic and metamorphic host rocks may be sources of uranfum for locally derived wedges of arkosic sedimentary rocks, now buried beneath adjacent valley alluvium. The uranium content of Pleistocene lacustrine sediments and playa lake brines is unknown. 
This report presents the results of a preliminary study of uranium occurrences in the beryllium belt of Juab County, Utah. The study was conducted by Bendix Field Engineering Corporation (BFEC) for the U.S. Energy Research and Development Administration (ERDA) to aid in estimating the uranium potential of the area.

\section{$\underline{\text { PURPOSE }}$}

The purposes of the project were: (1) to identify and describe geologic environments in the study area favorable for uranium resources; and (2) to recommend additional work necessary to better define the favorability and to allow a more accurate assessment of the uranium potential.

\section{LOCATION}

Juab County is in the central part of western Utah (Fig. 1; P1. 1). The project area encompasses $2,300 \mathrm{sq}$ mi, extending from $\mathrm{T}$. $11 \mathrm{~s}$. through T. 14 S., and from R. 4 W. through R. 19 W., Salt Lake Base and Meridian.

\section{PREVIOUS WORK}

Uranium exploration in Juab County has centered in the Thomas Range and Spor Mountain areas, where uranium was found in association with beryllium and fluorine mineralization. In recent years, major mining companies have staked numerous claims and conducted extensive core drilling operations in the Thomas Range area.

Three volcanic centers (Honeycomb Hills, Thomas Range, and Keg Mountains) have been mapped in detail (McAnulty and Levinson, 1964; Staatz and Carr, 1964; Staub-Blair, 1975). Uranium-bearing veins and pegmatites associated with granitic intrusives have been described in the Deep Creek Range (Thompson, 1973) and in Desert Mountain (Rees and others, 1973). Park (1968) and Shawe (1972) conducted regional studies to establish the temporal and spatial relationships of the various igneous rocks and the beryllium mineralization. Lindsey and others (1973) and Lindsey (1975b) studied hydrothermal alteration, particularly trace-element characteristics, in the Spor Mountain and Keg Mountain areas.

\section{PROCEDURES}

\section{FIELD INVESTIGATIONS}

Radioactivity anomalies described in Preliminary Reconnaissance Reports (M-1490; RR-78, 124, 125; SL-83, 113; SU-29; USGS-143-144, 146, 148, 2461467 ; open filed in 1966 by the U.S. Atomic Energy Commission) and all known uranium occurrences within the beryllium belt were examined and sampled during this 


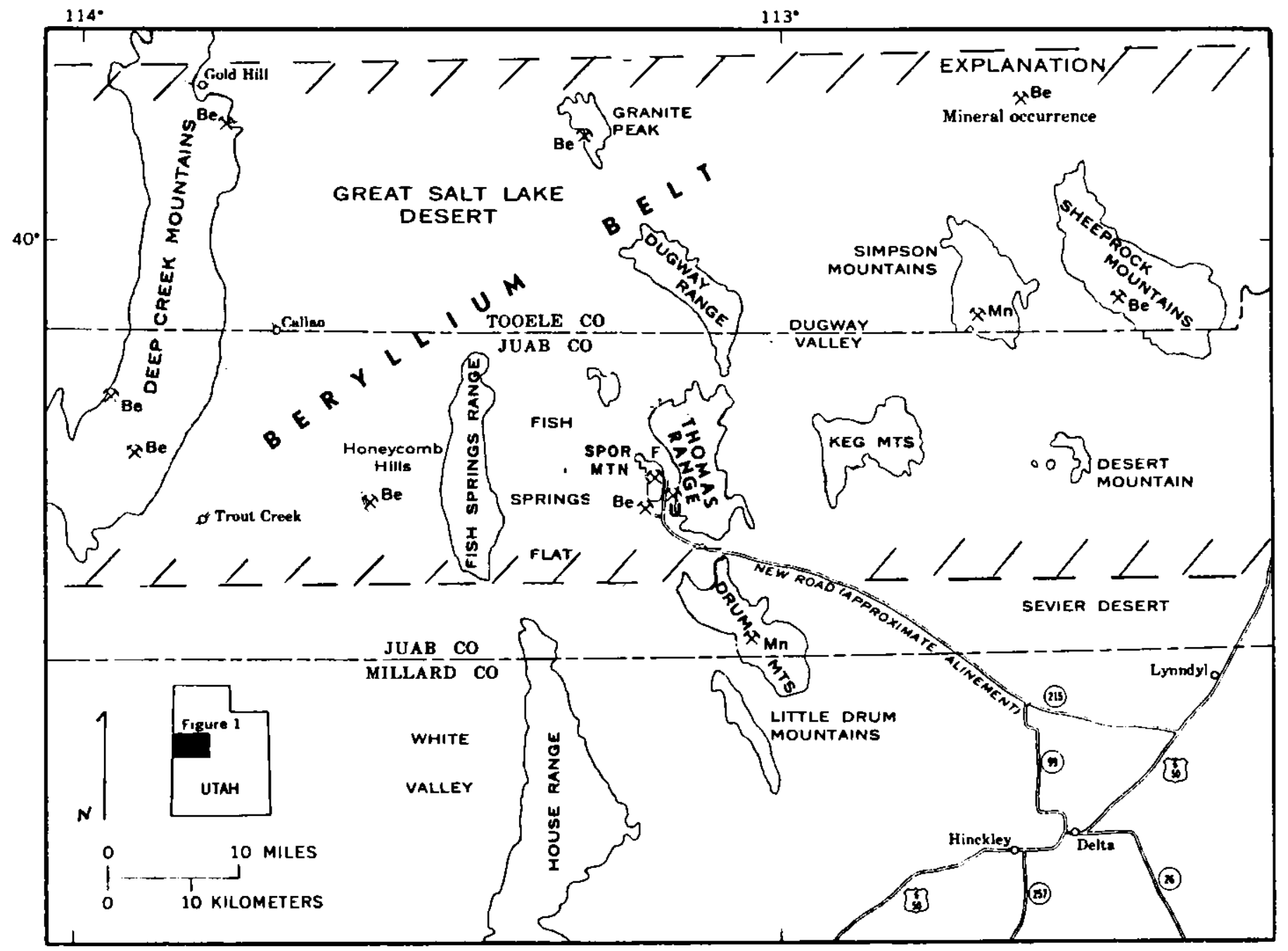

Figure 1. Mineral occurrences within the west central Utah beryllium be1t. (Modified from Lindsey and others, 1973) 
study. A few weak anomalies in the eastern part of Juab County, associated with volcanic rocks of Tertiary age, were excluded. Samples were collected from water-laid tuffs in the Thomas Range to aid in correlation of these tuffs with the beryllium-bearing tuffs at Spor Mountain.

A stratigraphic section of a beryllium-bearing tuff was measured and sampled at the Spider No. 1 mine in the Honeycomb Hills. Samples were taken at lithologic breaks within the tuff. A scintillometer survey was conducted over a 1-sq-mi area of trenches and adits.

Radiometric traverses were made and samples were collected from 01igocene and Miocene ash-flow tuffs in the Little Drum and Drum Mountains and from a Triassic intrusive in the House Range to determine background radioactivity. An anomaly at Long Ridge in Millard County was also sampled. The locations and lithologies of these samples are listed in Appendix A.

\section{SAMPLE ANALYSIS}

Sixty-six rock samples were collected and analyzed by wet chemistry for uranium, beryllium, and fluorine. Radiometric potassium, uranium, and thorium were determined by gamma-ray spectroscopy for all samples. Analytical results are listed in Appendix B. Petrographic studies were made on 21 selected samples.

\section{GEOLOGY}

\section{GENERAL STRATIGRAPHY}

The stratigraphy and geologic history of Juab County have been described in detail by Staatz and Carr (1964); therefore, only a brief summary of the pre-Tertiary stratigraphy is given here. Rocks ranging in age from Precambrian to Mississippian are found in the area (P1. 1). Precambrian rocks are schists, quartzites, and argillites, whereas the Paleozoic strata are mostly carbonates with minor sandstones and shales, ranging in age from Cambrian to Mississippian.

\section{TERTIARY GEOLOGY}

During much of Tertiary time, western Utah was dominated by the extrusion from widely spaced volcanic centers, of potassium-rich calc-alkalic to silicic volcanic flows and tuffs (Fig. 2). Important volcanic centers in Juab County are, from west to east, Honeycomb Hills, Thomas Range, Keg Mountains, and Desert Mountain (P1. 1). Granitic rocks form the cores of the Keg Mountains and Desert Mountain, and intrude sedimentary rocks of Paleozoic and Precambrian ages.

Radiometric age dating of volcanic rocks in west-central Utah (Lindsey and others, 1975) has delineated three distinct age groups. These three groups are herein referred to as the basal portion, medial portion, and upper portion (Fig. 3). 
Qtal Late Tertiary to Holocene colluvium and alluvium; includes Pleistocene lacustrine terrace deposits.

Tptf Pliocene topaz-bearing rhyolite flows and

Tps vitric tuffs; local tuffaceous sandstone, Tps.

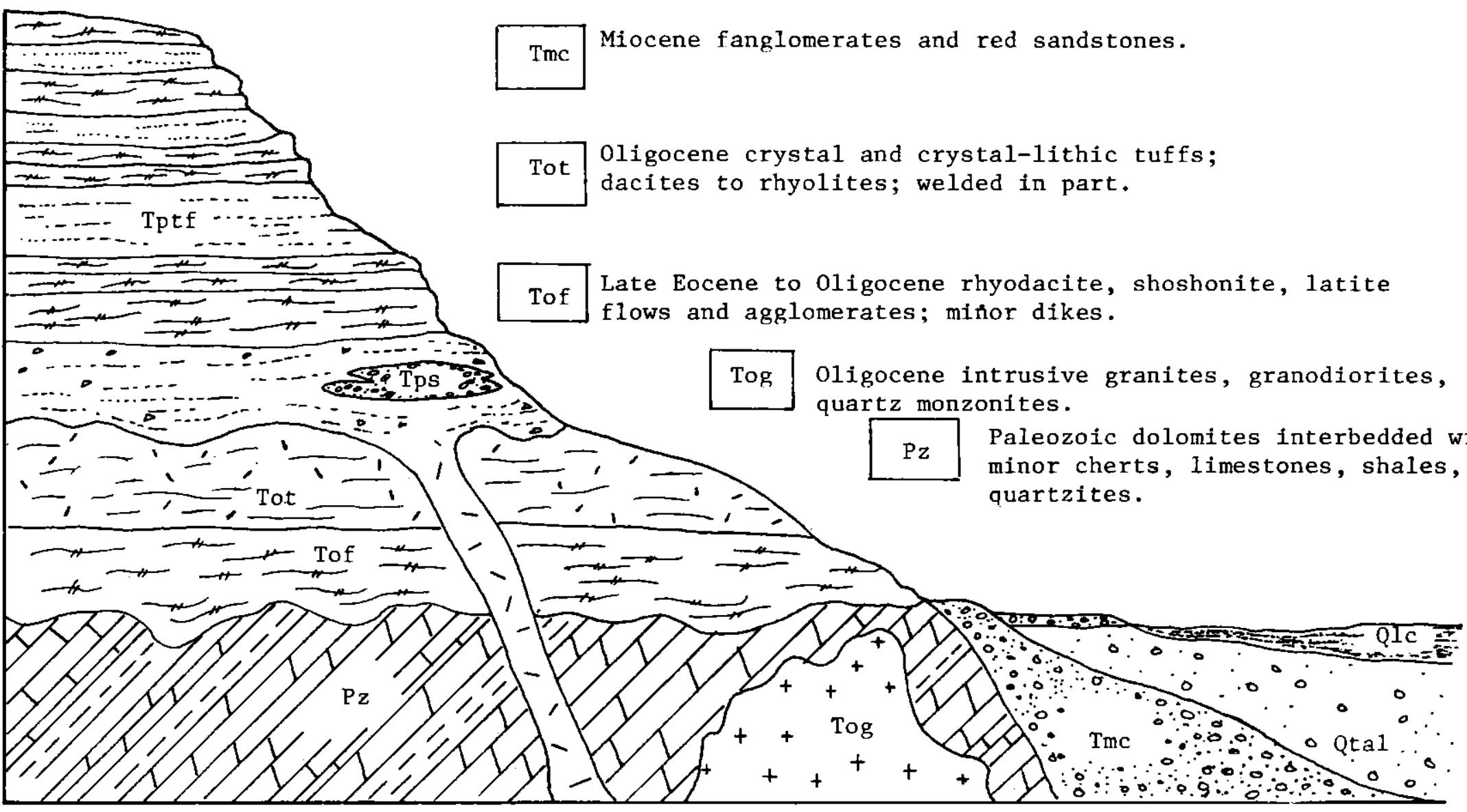

Figure 2. Simplified stratigraphic section, Juab County, Utah. 
The basal portion (late Eocene) consists of rhyodacite, shoshonite, and latite flows and agglomerates that unconformably overlies sedimentary rocks of Paleozoic age along the southern and western flanks of the Thomas Range (Fig. 2). Similar flows were extruded from volcanic centers at Honeycomb Hills, Fish Springs Flats, Little Drum Mountains, Desert Mountains, and west Tintic Mountains.

The medial portion (Oligocene and Miocene) is composed of dacitic to rhyolitic ash-flow tuffs that unconformably overlie the rocks of the basal portion. The ash-flow tuffs of the medial portion are exposed from the western flanks of the Thomas Range southward into the Drum Mountains, possibly reflecting a ring fracture formed by the collapse of the postulated Thomas caldera (Shawe, 1972). Granodiorite intrusions in the Keg Mountains and in Desert Mountain are thought to be the result of resurgent doming within two separate calderas (Shawe, 1972; Lindsey and others, 1975).

A period of erosion, lasting about $10 \mathrm{~m} . \mathrm{y}$. , began in late Oligocene time and continued through most of Miocene time. Evidence for this erosional hiatus is found in the widespread fanglomerates and sandstones, derived from major basin-and-range fault blocks, that accumulated during Miocene time.

The upper portion (P1iocene) of the volcanic sequence consists of rhyolite flows, tuffs, and tuffaceous sands. Rocks of the upper portion, the most extensively exposed lithologic units in the Thomas Range and Keg Mountains volcanic centers, contain all of the known uranium anomalies and deposits associated with volcanic rocks in Juab County.

\section{$\underline{\text { STRUCTURE }}$}

The topographic features of Juab County reflect the latest major tectonic activity, basin-and-range faulting. Although some of the major faults are eroded or lie buried beneath alluvium, others are obvious along the eastern flanks of Spor Mountain and the Dugway Range, and on the western flank of the Sheeprock Mountains.

The volcanic centers are aligned in an east-west direction, apparently controlled by a deep-seated structural feature over $80 \mathrm{mi}$ long (Erickson, 1963, p. 34). Pre-basin-and-range folding, thrust faulting, and the collapse of calderas affected sedimentary rocks of Paleozoic age and the basal and medial portions of the volcanic rock sequence.

Several phases of the Late Cretaceous to early Paleocene Laramide orogeny, consisting in sequence of (1) initial broad folding, (2) thrust faulting, and (3) strike-slip faulting, are most obvious in sedimentary rocks of Paleozoic age that form the flanks of the Thomas Range and Sheeprock Mountains. Major northeast-trending thrust faults, low- to high-angle transverse faults, and strike-slip faults that formed during the Laramide orogeny have been offset by later north-trending basin-and-range normal faults. Major intersections of these fracture systems have formed structurally complex blocks, such as Spor Mountain. Most basin-and-range fault blocks in the area are tilted to the west, but the House Range is tilted to the east. 


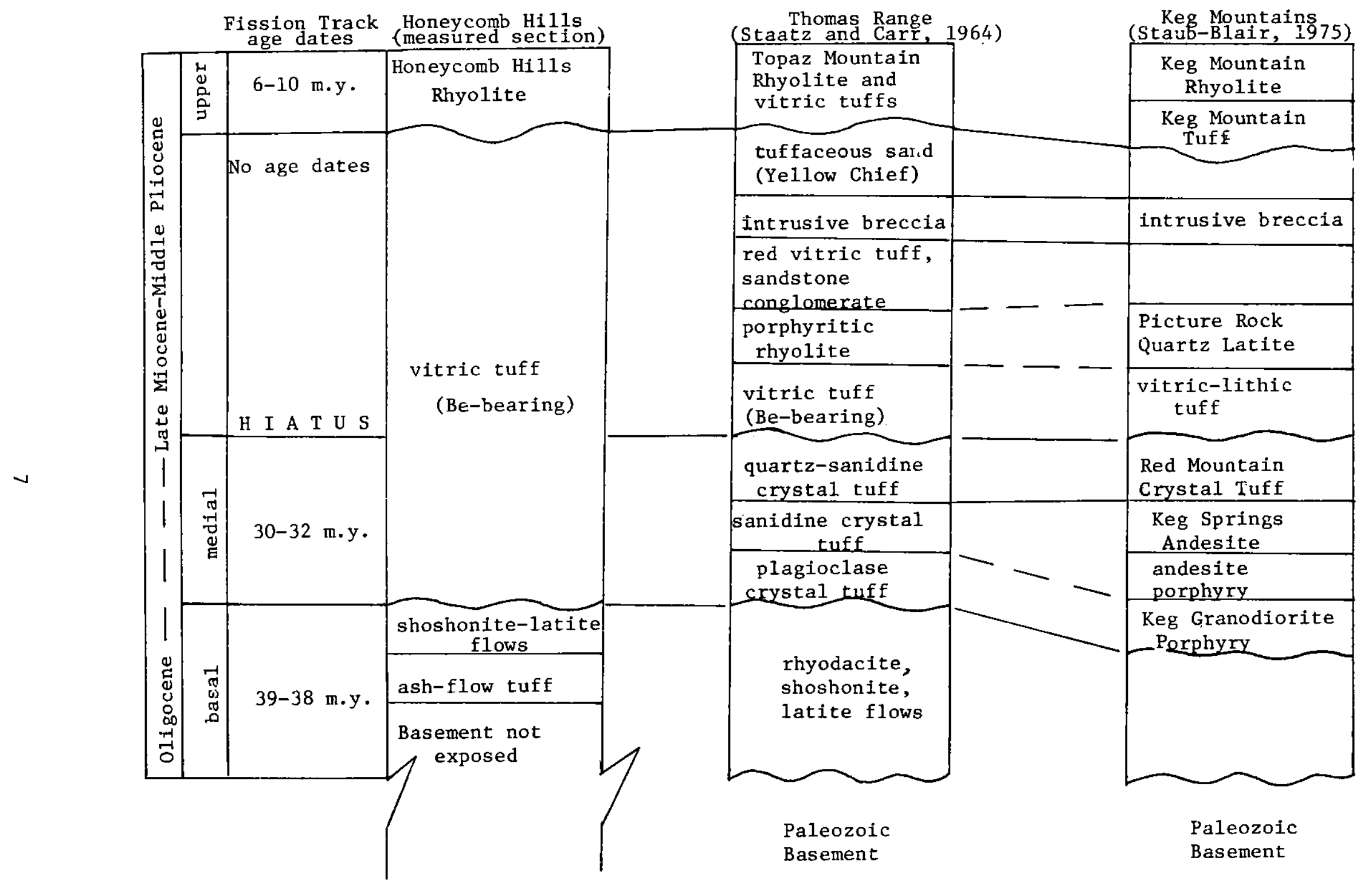

Figure 3. Correlation chart for stratigraphic sections in Juab County, Utah. 
Collapse of the Thomas caldera formed an arcuate ring fracture that displaced sedimentary rocks of Paleozoic age on the southwest rim of the caldera. Other caldera ring-fracture zones are inferred from the increase in thickness of ash-flow tuffs within the caldera interiors and from arcuate distribution patterns of faults, dikes, and plugs (Shawe, 1972).

\section{URANIUM FAVORABILITY}

Three major rock units in Juab County, Utah, are favorable for hypogene uranium resources. The favorability is based principally upon known uranium deposits in each unit. Three other rock units are favorable for supergene uranium deposits.

\section{HYPOGENE DEPOSITS}

Late-stage differentiation of magma beneath the west-central Utah beryllium belt concentrated beryllium, fluorine, and uranium. This differentiation should have produced similar ratios of these elements in the hypogene deposits that occur in a variety of host rocks. These deposits include: (1) fluorspar veins, pipes, and replacement deposits in dolomite rocks of Paleozoic age; (2) hydrothermally altered vitric tuffs of Pliocene(?) age; (3) pegmatite dikes and metalliferous veins in granitic rocks of Tertiary age; and (4) Holocene tufa mounds associated with radioactive. hot springs.

\section{Dolomite Rocks}

Fluorspar pipes, veins, and replacement deposits occur in a series of dolomite rocks, Middle Ordovician to Middle Devonian in age, at Spor Mountain in T. 12 S. and T. 13 S., R. 12 W. (Staatz and Carr, 1964, p. 132). Fifty known uraniferous fluorspar deposits are found in this intensely faulted structural block. The dolomite rocks are light gray to black, massive to thin-bedded, and fine grained or sandy textured, with numerous small parallel bands of gray or pink cherts.

Most of the uraniferous fluorspar deposits are localized by northeasttrending faults, but the larger pipes have no obvious structural control. The pipes may become narrow or split at depth, and many plunge steeply toward the east (Staatz and Carr, 1964, p. 130). Steeply dipping smaller veins, common1y adjacent to pipes, cut orthoquartzites of Cambrian age and, locally, rhyodacite of oligocene age. The uranium contents of the deposits range from 0.003 to 0.33 percent $\mathrm{U}_{3} \mathrm{O}_{\mathrm{\theta}}$ (Staatz and Carr, 1964, p. 136-137). 
Granitic Rocks and Pegmatite Dikes

Desert Mountain (T. 12 S., R. 7 W.) is composed mostly of fine-grained granodiorite, Oligocene in age, intruded by younger granite. Both granitic bodies are cut by pegmatite, aplite, and lamprophyre dikes. The granodiorite and granite locally grade into quartz monzonite phases.

At the Rockwell Shaft (NW $1 / 4$ sec. $28, T .12$ s., R. 7 W.), on the western flanks of Desert Mountain, is a vein that contains uranium $\left(0.17 \% \mathrm{U}_{3} \mathrm{O}_{8}\right)$, copper sulfides and oxides, tetrahedrite, galena, and pyrite in quartz and barite gangue (Rees and others, 1973). The vein strikes $\mathrm{N} .10^{\circ} \mathrm{W}$. and dips $60^{\circ} \mathrm{W}$. along the contact of a lamprophyre dike in the granite. Mineralization is controlled in part by northeast-trending shear zones that cut the vein.

In Trout Canyon (sec. 28, T. 12 S., R. 18 W.), several adits were driven along northwest-trending pegmatite dikes in the Precambrian Trout Creek Formation. A sample from a small 1-ft-wide quartz-muscovite-beryl pegmatite dike that intruded muscovite-biotite schists contained 51 ppm $\mathrm{U}_{3} \mathrm{O}_{8}$. The pegmatite dikes in Trout Creek Canyon grade laterally into an alaskite intrusive of Miocene age that is exposed over a 1/4-sq-mi area in the NE $1 / 4$ of sec. 28 (Thompson, 1973, p. 14). Similar pegmatite dikes that contain scheelite and fluorite were found at the Apex mine area in Granite Canyon (sec. 21, T. 12 S., R. $18 \mathrm{~W}$ ).

Hydrothermally Altered Vitric Tuffs (Beryllium-bearing Tuffs)

Hydrothermally altered vitric tuffs have good potential for large, lowgrade uranium deposits. They crop out on the northern and eastern flanks of Honeycomb Hills (sec. 1, T. 13 S., R. 16 W., and sec. 6, T. 13. S., R. 15 W.) and completely encircle Spor Mountain (Tps. 12 and 13 S., R. 12 W.). The white to grayish-orange-pink tuffs contain quartz, sanidine, plagioclase, and biotite in a matrix of silica and white or pink montmorillonite clay. Volcanic fragments, chert, and disseminated crystallites and nodules of fluorite are common. Mine pits at Spor Mountain expose conglomeratic lenses, up to $10 \mathrm{ft}$ thick, of fluorite-replaced dolomite nodules that extend for $200 \mathrm{ft}$ or more along strike before they pinch out or are terminated by low-angle or beddingplane faults. Fault fractures are commonly filled with manganese oxides. Altered magnesium-rich montmorillonite clays containing beryllium are found at Spor Mountain and in the Honeycomb Hills (Montoya and others, 1963, 1964).

The beryllium-bearing tuff at Spor Mountain probably discontinuously underlies a 120-sq-mi area encompassing the Thomas Range (Fig. 4). Most of the tuff is unfavorable for uranium deposits because of the distance from the ring-fracture system and sources of dolomite detritus. The most favorable area for mineralization is found along the western part of the Thomas caldera ring-fracture zone, marked by caldera walls composed of Paleozoic dolomites. Here, hydrothermal solution migration is most intense and may permeate favorable horizons within the tuff (Fig. 4). The extreme northern and southern parts of the inferred ring-fracture zone are not considered as favorable because of discontinuous deposition and subsequent erosion of the beryllium-bearing tuff. 


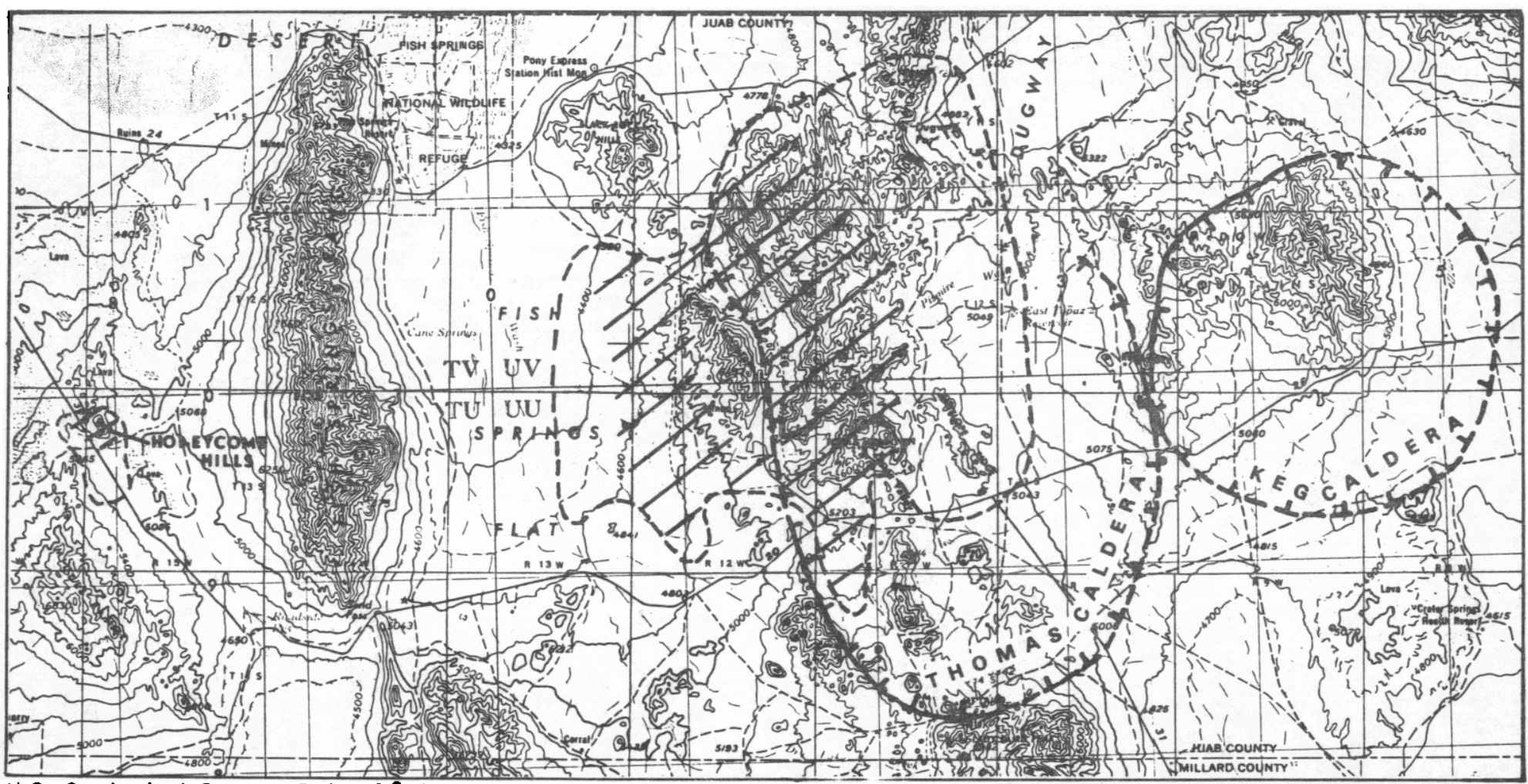

U.S. Geological Survey, Delta $2^{\circ}$ NTMS

Scale: $1: 23,280$

8

12

Miles

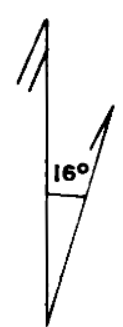

Figure 4. Favorable areas for uranium deposits in beryllium-bearing tuffs. 
A vitric-lithic tuff, similar to the beryllium-bearing tuff, in the Keg Mountains may underlie an area of $150 \mathrm{sq}$ mi within a second caldera east of the Thomas caldera. No surface evidence of hydrothermal alteration was found along the postulated ring-fracture zone on the north flank of the Keg Mountains; thus this tuff may not be mineralized. However, this area is considered favorable because of its similarity to the Thomas caldera.

An altered tuff at the Spider No. 1 mine in the Honeycomb Hills (sec. 1 , T. 13 S., R. 16 W.) is overlain by a topaz-bearing rhyolite flow (P1. 1 ). Adits have been driven along the tuff-rhyolite contact on the west and north sides of the Honeycomb Hills, and trenches expose the contact on the east side. The highest uranium concentrations are found in the upper $3 \mathrm{ft}$ of the altered tuff in a zone of fluorite-replaced dolomite nodules and pink to white montmorillonite clays. Fracture fillings, within the altered tuff and overlying rhyolite flow, contain uraniferous opal. Samples from a 20-ft section of a series of three white to light-orange units in the altered tuff con-

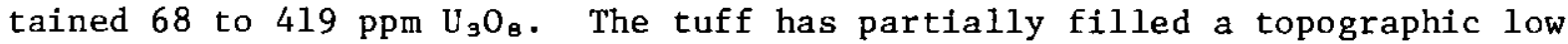
of perhaps $7 \mathrm{sq} \mathrm{mi}$ around the Honeycomb Hills rhyolite plug. The altered part of the tuff is found only in a 1-sq-mi area and probably does not exceed $30 \mathrm{ft}$ in thickness. On the north and east sides of the rhyolite plug, northeast-trending fractures in an explosive breccia at the base of the rhyolite flow are coated with autunite. Selected samples of this breccia contained up to $113 \mathrm{ppm} \mathrm{U}_{3} \mathrm{O}_{8}$. The impervious rhyolite flow may have acted as a barrier to ascending hydrothermal solutions, forcing them to diffuse outward so the uranium was fixed within the fluorite-replaced nodules and within the montmorillonite matrix clays. A similar origin is postulated for the uranium in the beryllium-bearing tuffs at Spor Mountain.

\section{Tufa Mounds}

Tufa mounds deposited at two radioactive hot springs are host for lowgrade uranium. These mounds are exposed over approximately 10 acres at Wilson Hot Springs and over 2 acres at Baker Hot Springs. The tufa is friable calcareous cellular rock with secondary iron oxides, manganese oxides, and gypsum.

The Wilson Hot Springs are in sec. 33, T. $10 \mathrm{~S} .$, R. $14 \mathrm{~W}$. at the north end of Fish Springs Range. The more encrusted unvegetated mounds adjacent to these springs have the highest gamma count, 2,000 to 5,000 cps, and are present in an area of about 2 acres. Heavily vegetated mounds, with gamma counts of 1,200 to $1,600 \mathrm{cps}$, are found in a 10-acre area extending in a northeastward direction. Most of the radioactivity is probably caused by radon gas and its daughter products. The northeast trend is also exhibited by four springs surrounded by the most recent tufa deposits. A sample from these tufa deposits contained 0.20 percent $\mathrm{eU}_{3} \mathrm{O}_{8}$.

The Baker Hot Springs are in sec. 10, T. 14 S., R. 8 W., on the east side of Fumarole Butte, a small shield basalt flow. Several hot springs are aligned northward, although several inactive ponds lie outside this trend. One sample from a tufa mound contained $93 \mathrm{ppm} \mathrm{U}_{9} \mathrm{O}_{8}$; another contained 2,900 ppm $\mathrm{eU}_{3} \mathrm{O}_{8}$. A water sample from one of the springs contained only $2 \mathrm{ppb} \mathrm{U}_{3} \mathrm{O}_{8}$. 
Long Ridge in Millard County, Utah, has outcrops of radioactive tufa, similar to those at Wilson and Baker Hot Springs. Data collected from Long Ridge are included in the appendices for comparison.

\section{SUPERGENE DEPOSITS}

The beryllium-, fluorine-, and uranium-enriched magma that produced the hypogene fluids also supplied these elements to granitic bodies of Miocene age and to rhyolitic flows and tuffs of Pliocene age. The topaz-bearing rhyolites in Juab County have three times the average uranium content of rhyolites within the United States (Staatz and Carr, 1964, p. 116), and there are an estimated $20 \mathrm{cu} \mathrm{mi}$ of these rhyolites within the Honeycomb Hills, Thomas Range, and Keg Mountain volcanic centers (Erikson, 1963, p. 34). Rhyolitic rocks in the study area contain from 19 to $25 \mathrm{ppm} \mathrm{U}_{3} \mathrm{O}_{8}$ at Honeycomb Hills, from 9 to $23 \mathrm{ppm} \mathrm{U}_{3} \mathrm{O}_{8}$ in the Thomas Range, and $10 \mathrm{ppm} \mathrm{U}_{3} \mathrm{O}_{8}$ at Fumarole Butte. Vitric and vitric-lithic tuffs alternating with the topaz rhyolite flows contain from 9 to 25 ppm $\mathrm{U}_{3} \mathrm{O}_{8}$. Leaching of these flows and tuffs by circulating ground waters could form higher-grade concentrations in lacustrine clays or brines in the Great Salt Lake, Fish Springs Flat, Sevier Lake, and Tule Valley.

\section{Tuffaceous Sandstone}

According to U.S. Department of Energy records at the Grand Junction Office, the U.S. Atomic Energy Commission purchased 105,132 tons of ore, averaging 0.20 percent $\mathrm{U}_{3} \mathrm{O}_{8}$ and containing $425,344 \mathrm{lbs}$ of $\mathrm{U}_{3} \mathrm{O}_{8}$, from a uranium deposit in tuffaceous sandstone at the Yellow Chief mine (NW $1 / 4 \mathrm{sec}$. 36, T. $12 \mathrm{~S} ., \mathrm{R}$. 12 W.). Uranium occurs in porous quartz-sanidine sandstone, white to yellowishgreen in color, that is coarse grained, moderately sorted, and contains pebble and cobble conglomerate-filled channels. The sandstone is $30 \mathrm{ft}$ thick, dips $20^{\circ} \mathrm{NW}$, and is underlain by crystal tuffs and overlain by limestone conglomerates.

The uranium is associated with zones of high porosity and permeability in the Yellow Chief tuffaceous sandstone. No organic debris or other evidence of a reducing environment are apparent. Intergranular disseminated betauranophane, carnotite, autunite, and schroeckingerite veinlets are confined to the coarser sandstone fractions and conglomerate lenses (Staatz and Carr, 1964, p. 154). A ground scintillometer survey detected several anomalies associated with these lithologies. Two significant anomalies, four to five times background ( 800 to $1,000 \mathrm{cps}$ ), were found where small festoonlike iron oxide structures had developed in medium- to coarse-grained sandstone. A sample from one of these anomalies contained $30 \mathrm{ppm} \mathrm{U}_{3} \mathrm{O}_{8}$. These sandstones, 3 to $10 \mathrm{ft}$ thick, are interbedded with medium-gray claystone and siltstone. The Yellow Chief sandstone is in a downthrown fault block, now exposed by erosion, and rocks exposed in adjacent fault blocks are older than the sandstone. The downthrown fault block probably does not exceed $1 \mathrm{mi}$ in length or $1,200 \mathrm{ft}$ in width. Reworked tuffaceous sandstone, similar to the Yellow Chief sandstone, may be perserved in fault blocks beneath alluvium along the inferred southern continuation of the ring-fracture zone in the northwest Drum Mountains (T. 13 S., R. 11 W.). 
Vitric Tuffs and Rhyolite Flows (Upper Portion)

A series of five subunits in the upper part of the volcanic sequence were distinguished by Staatz and Carr (1964, p. 86). Each subunit consists of a vitric tuff and an overlying rhyolite flow. The rhyolite flows overlie vitric tuffs in each of the subunits and consist of three facies: lower obsidian facies, central red spherulitic facies, and upper gray rhyolite facies. The flows contain 10 to 20 percent phenocrysts of quartz, sanidine, and plagioclase in an allotriomorphic granular groundmass of quartz and sanidine intergrowths and spherulites. The flows are distinguished by topaz phenocrysts and secondary vug fillings of topaz.

Uraniferous opal vein and fracture fillings are found in two deposits in rhyolitic flows and vitric tuffs in the Thomas Range. At the Buena No. 1 deposits (sec. 11, T. 13 S., R. 12 W.), steeply dipping $1 / 8$ to $1 / 2$ in.wide fractures in a topaz rhyolite flow are fllled with opal that contains 0.02 percent $\mathrm{eU}_{3} \mathrm{O}_{3}$ (Staatz and $\mathrm{Carr}, 1964, \mathrm{p}$. 135). Although the deposit was not found during this study, a basal obsidian facies of the topaz rhyolite flow and an underlying pumice lapilli tuff in sec. 11 contained anomalous uranium values of 23 and $25 \mathrm{ppm} \mathrm{U}_{3} \mathrm{O}_{8}$, respectively. The Autunite No. 8 deposit (sec. 10, T. 13 S., R. 11 W.), on the east side of the Thomas Range, contains uraniferous opal in numerous steeply dipping veins up to $1 / 4 \mathrm{in}$. wide. The veins, in a porphyritic rhyolite flow and an overlying vitriclithic tuff, trend from northwest to northeast and are exposed over an area $100 \mathrm{ft}$ long by $25 \mathrm{ft}$ wide. Channel samples of the mineralized areas contained 0.009 to 0.03 percent $\mathrm{eU}_{3} \mathrm{O}_{\mathrm{s}}$ and a selected sample of vein material contained 0.02 percent $\mathrm{eU}_{3} \mathrm{O}_{a}$ (Staatz and $\mathrm{Carr}, 1964, \mathrm{p}$. 153). A sample of the rhyolite flow, which included opal vein filling, contained $6 \mathrm{ppm} \mathrm{U}_{3} \mathrm{O}_{3}$. Scintillometer traverses made across vitric tuffs in the Thomas Range revealed two additional radioactivity anomalies. The anomalies are three times background (500 to $600 \mathrm{cps}$ ) and are related to opalized veins and fracture fillings.

\section{Arkosic Sedimentary Rocks}

Intrusive equivalents of volcanic rocks, such as the Sheeprock Granite

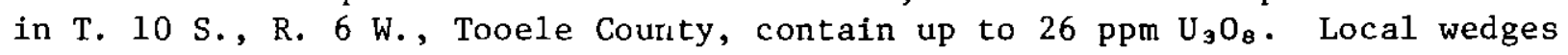
of arkosic sedimentary rocks may have developed at the margins of the basins (P1. 1). These wedges may lie buried beneath the alluvium fill. Similar arkosic wedges may have formed at intervening basin margins adjacent to the Deep Creek Range and Desert Mountain.

\section{CONCLUSIONS}

The best potential for large, low-grade uranium deposits in Juab County is in the hydrothermally altered vitric tuffs of Pliocene(?) age. The lateral extent of the altered tuffs may be determined by subsurface studies around the perimeter of the volcanic centers in the Thomas Range and the Honeycomb Hills. 
Because the ring-fracture zone associated with collapse of the Thomas caldera was a major control for hydrothermal uranium deposits, delineation of the northern and eastern positions of the ring-fracture zone is critical in defining favorable areas for uranium deposits.

A small, medium-grade ore deposit in tuffaceous sand of Pliocene(?) age at the Yellow Chief mine in Dugway Dell is unique in origin, and the probability of discovering another deposit of this type is low. A deposit of this type may be present under alluvial cover in the northwestern Drum Mountains along the southern extension of the ring-fracture zone of the Thomas caldera. Festoonlike iron oxide structures and uranium deposition within permeable sandstone horizons indicate that the Yellow Chief deposit was formed by recent ground-water circulation.

Granitic intrusive rocks in the Deep Creek Range and in Desert Mountain contain isolated epigenetic vein-type deposits. These rocks could be a source of arkosic sediments buried in adjacent valleys.

The Pleistocene lacustrine sediments and playa lake brines may contain concentrations of uranium leached from uranium-rich rocks. 


\section{BIBLIOGRAPHY}

Bowyer, Ben, 1963, Yellow Chief uranium mine, Juab County, Utah, in Beryllium and uranium mineralization in western Juab County, Utah: Utah Geol. Soc., Guidebook to the Geology of Utah, no. 17, p. 15-22.

Calkins, W. G., 1970, Magnetic and gravity study of Desert Mountain, Juab County, Utah: Utah Geol. and Mineralog. Survey Bull. 95, 21 p.

Erickson, M. P., 1963, Volcanic geology of western Juab County, Utah, in Beryllium and uranium mineralization in western Juab County, Utah: Utah Geo1. Soc., Guidebook to the Geology of Utah, no. 17, p. 23-35.

Griffitts, W. R., 1964, Beryllium in mineral and water resources of Utah: Utah Geol. and Mineralog. Survey Bul1. 73, p. 71-75.

Hintze, L. F., 1963, Utah, southwest quarter: Utah Geol. and Mineralog. Survey, scale $1: 250,000$.

Kattleman, D. F., 1968, Geology of the Desert Mountain intrusives, Juab County, Utah: Brigham Young Univ. Geol. Studies, v. 15, p. 85-107.

Lindsey, D. A., 1975a, Mineralization halos and diagenesis in water-laid tuffs of the Thomas Range, Utah: U.S. Geol. Survey Prof. Paper 818-B, $59 \mathrm{p}$.

1975b, The effect of sedimentation and diagenesis on trace element composition of water-laid tuff in the Keg Mountain area, Utah: U.S. Geol. Survey Prof. Paper 818-C, 35 p.

Lindsey, D. A., Ganow, H., and Mountjoy, W., 1973, Hydrothermal alteration associated with beryllium deposits at Spor Mountain, Utah: U.S. Geol. Survey Prof. Paper 818-A, 20 p.

Lindsey, D. A., Naeser, C. W., and Shawe, D. R., 1975, Age of volcanism, intrusion, and mineralization in the Thomas Range, Keg Mountairi, and Desert Mountain, western Utah: U.S. Geol. Survey Jour. Research, v. 3, no. 5, p. 597-604.

McAnulty, W. N., and Levinson, A. A., 1964, Rare alkali and beryllium mineralization in volcanic tuffs, Honeycomb Hills, Juab County, Utah: Econ. Geology, v. 59, p. 768-774.

Montoya, J. W., Havens, R., and Bridges, D. W., 1963, Beryllium-bearing tuff from Spor Mountain Utah -- Its chemical, mineralogical, and physical properties: U.S. Bur. Mines Rept. Inv. 6094, 15 p.

Montoya, J. W., Baur, G. S., and Wilson, S. R., 1964, Mineralogica1 investigation of beryllium-bearing tuff, Honeycomb Hills, Juab County, Utah: U.S. Bur. Mines Rept. Inv. 6408, 11 p.

Newel1, R. A., 1971, Geology and geochemistry of the northern Drum Mountains, Juab County, Utah [M.S. Thesis]: Golden, Colorado School Mines, 115 p. 
BIBLIOGRAPHY (continued)

Patton, H. B., 1908, Topaz-bearing rhyolite of the Thornas Range, Utah: Geol. Soc. America Bull., v. 19, p. 177-192.

Park, G. M., 1968, Some geochemical and geochronological studies of the beryllium deposits in western Utah [M.S. Thesis]: Salt Lake City, Univ. of Utah, $105 \mathrm{p}$.

Rees, D. C., Erickson, M. P., and Whelan, J. A., 1973, Geology and diatremes of Desert Mountain, Utah: Utah Geol. and Mineralog. Survey Spec. Studies 42, $12 \mathrm{p}$.

Robinson, P. T., McKee, E. H., and Moiola, R. J., 1968, Cenozoic volcanism and sedimentation, Silver Peak region, western Nevada and adjacent California, in Studies in volcanology: Geol. Soc. America Mem. 116, p. 577-611.

Rosholt, J. N., Prijana, and Noble, D. C., 1971, Mobility of uranium and thorium in glassy and crystallized silicic volcanic rocks: Econ. Geology, v. 66, no. 7, p. 1061-1069.

Shawe, D. R., 1966, Arizona-New Mexico and Nevada-Utah beryllium belts, in Geological Survey Research 1966; U.S. Geol. Survey Prof. Paper 550-C, p. C206-C213.

1968, Geology of the Spor Mountain beryllium district, Utah, in Ore deposits of the United States (Graton-Sales Vol.), Vol. 2: New York, Am. Inst. Mining, Metall. and Petroleum Engineers, p. 1148-1161.

1972, Reconnaissance geology and mineral potential of Thomas, Keg, and Desert calderas, central Juab County, Utah, in Geological Survey Research 1972: U.S. Geo1. Survey Prof. Paper 800-B, P. B67-B77.

Staatz, M. H., 1963, Geology of the beryllium deposits in the Thomas Range, Juab County, Utah: U.S. Geol. Survey Bull. 1142-M, 36 p.

Staatz, M. H., and Bauer, H. L., Jr., 1950, Preliminary examination of the uranium prospect at the Spider No. $1 \mathrm{claim}$, Honeycomb Hills, Juab County, Utah: U.S. Geol. Survey Trace Element Memo. Rept. 165, published by U.S. Atomic Energy Comm., 7 p.

Staatz, M. H., and Carr, W. J., 1964, Geology and mineral deposits of the Thomas and Dugway Ranges, Juab County, Utah, and Tooele County, Utah: U.S. Geol. Survey Prof. Paper 415, 188 p.

Staatz, M. H., and Osterwald, F. W., 1959, Geology of the Thomas Range fluorspar district, Juab County, Utah: U.S. Geo1. Survey Bu11. 1069, 97 p.

Staub-Blair, B. A., 1975, Geology of the Picture Rock quadrangle, southwestern Keg Mountains, Juab County, Utah [M.S. Thesis]: Salt Lake City, Univ. of Utah, $91 \mathrm{p}$. 


\section{BIBLIOGRAPHY (continued)}

Stokes, W. L., 1962, Utah, northwest quarter: Utah Geol. and Mineralog. Survey, scale 1:250,000.

Thompson, K. C., 1973, Mineral deposits of the Deep Creek Mountains, Tooele and Juab Counties, Utah: Utah Geol. and Mineralog. Survey Bul1. 99, $76 \mathrm{p}$.

U.S. Geological Survey, 1953, Delta quadrangle, Utah: scale 1:250,000.

Whelan, J. A., 1970, Radioactive and isotopic age determinations of Utah rocks: Utah Geol. Soc. Bul1. $81,75 \mathrm{p}$.

Williams, N. C., 1963, Beryllium deposits, Spor Mountain, Utah, in Beryllium and uranium mineralization in western Juab County, Utah: Utah Geol. Soc. Guidebook to the Geology of Utah, no. 17, p. 35-59. 

APPENDIX A

LOCATIONS AND LITHOLOGIES OF SAMPLES 
APPENDIX A. LOCATIONS AND LITHOLOGIES OF SAMPLES

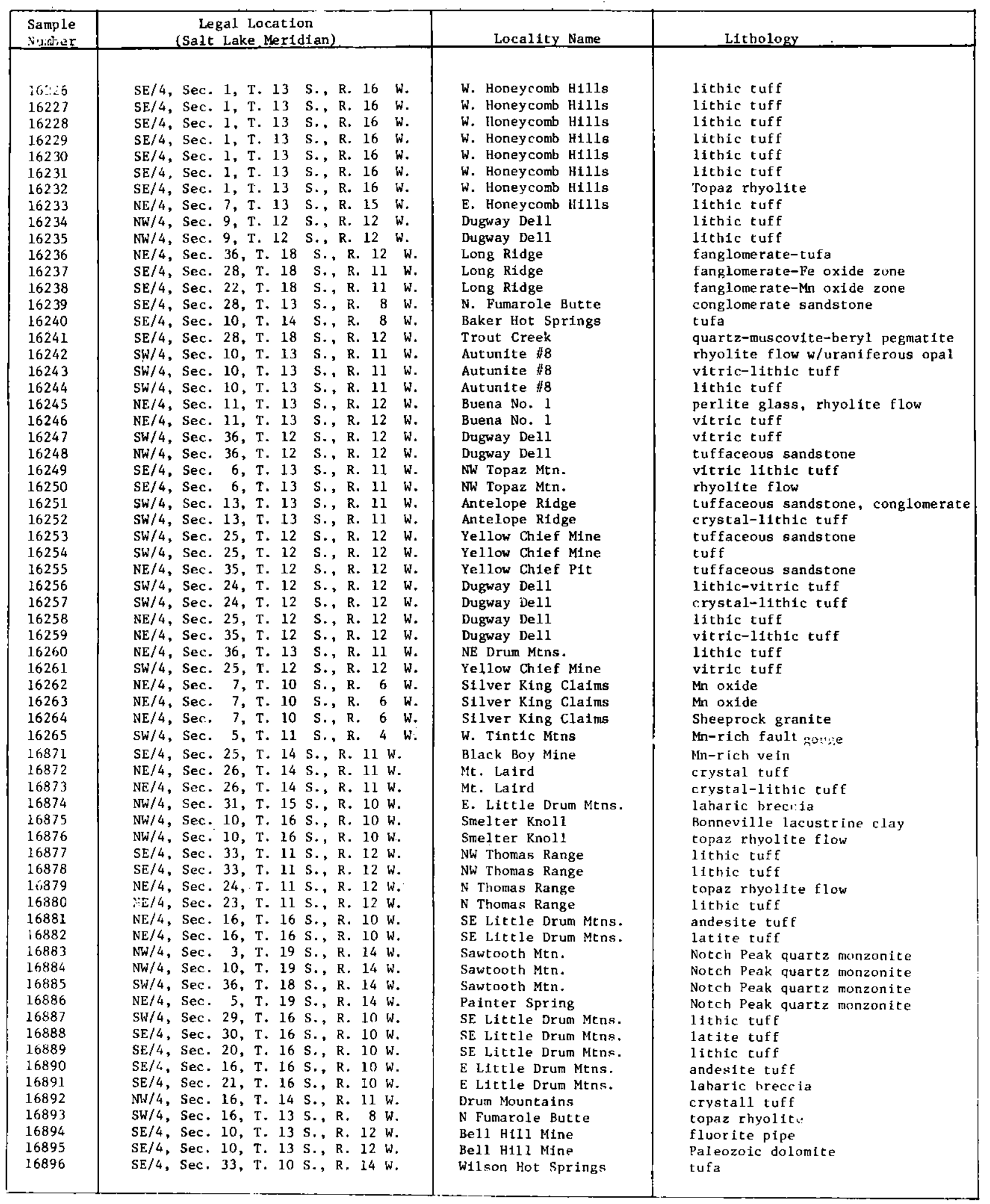


APPENDIX B

ANALYTICAL DATA 
APPENDIX B. ANALYTICAL DATA

\begin{tabular}{|c|c|c|c|c|c|c|c|c|}
\hline \multirow[b]{2}{*}{ Sam:1,.. thumber } & \multicolumn{3}{|c|}{ Gamma Spectroscopy } & \multirow[b]{2}{*}{$\begin{array}{l}\mathrm{cU}_{3} \mathrm{O}_{8} \\
(\mathrm{ppm})\end{array}$} & \multirow[b]{2}{*}{$\begin{array}{c}\mathrm{Be} \\
(\mathrm{ppm})\end{array}$} & \multirow[b]{2}{*}{$\begin{array}{c}F \\
(p ? m)\end{array}$} & \multirow[b]{2}{*}{$\begin{array}{c}\text { Surface } \\
\text { putinnetrics } \\
\text { (cps) }\end{array}$} & \multirow[b]{2}{*}{$\begin{array}{l}\text { Sample } \\
\text { Internal } \\
\text { (feet) }\end{array}$} \\
\hline & $\begin{array}{l}\text { Equivalent } \\
\text { Potassium } \\
\text { (percent) }\end{array}$ & $\begin{array}{c}\text { Equivalent } \\
\text { Uranium } \\
\text { (ppm) }\end{array}$ & $\begin{array}{l}\text { Equivalent } \\
\text { Thorfum } \\
\text { (ppm) }\end{array}$ & & & & & \\
\hline 16226 & 3.08 & 63.7 & 18.5 & 68 & 78 & 2.14 & 1000 & 2 \\
\hline 16227 & 2.42 & 256.6 & 19.5 & 256 & 78 & 2.04 & 1500 & 2 \\
\hline 16228 & 1.90 & 495.8 & 25.4 & 491 & 90 & 3.06 & 2500 & 3 \\
\hline 16229 & 2.24 & 425.1 & 21.0 & 519 & 126 & 4.96 & 3500 & 3 \\
\hline 16230 & 1.89 & 590.6 & 28.7 & 93 & 36 & 1.47 & 1850 & 2 \\
\hline 16231 & 1.08 & 384.9 & 20.2 & 380 & 60 & 3.41 & 2800 & 3 \\
\hline 16232 & 3.08 & 61.1 & 30.3 & 84 & 39 & 2.30 & 1000 & 3 \\
\hline 16233 & 2.39 & 39.7 & 26.9 & 43 & 30 & 1.71 & 600 & 3 \\
\hline 16234 & 4.40 & 22.8 & 43.5 & 70 & 228 & .59 & 500 & 10 \\
\hline 162.35 & 4.05 & 16.4 & 50.4 & 26 & 42 & .38 & 500 & 10 \\
\hline 16236 & $\because 1.69$ & 25.1 & 6.1 & 12 & 29 & .39 & 160 & 6 \\
\hline 16237 & 0.22 & 60.1 & 2.1 & 63 & 13 & $<.10$ & 450 & 6 \\
\hline 16238 & 1.34 & 149.9 & 6.8 & 212 & 11 & .68 & 600 & 10 \\
\hline 16239 & 5.43 & 4.3 & 15.6 & 5 & 6 & $<.10$ & 200 & 10 \\
\hline 16240 & 0.12 & 101.1 & 3.4 & 93 & 54 & $<.10$ & 6000 & 3 \\
\hline 16241 & 3.41 & 49.7 & 19.2 & 51 & 6 & .14 & 100 & 3 \\
\hline 16242 & 6.08 & 5.1 & 2.4 & 6 & 20 & .50 & 800 & 3 \\
\hline 16243 & 2.92 & 13.5 & 45.3 & 15 & 6 & .23 & 550 & 3 \\
\hline 16244 & 3.59 & 7.6 & 23.1 & 9 & 4 & $<.10$ & 350 & 10 \\
\hline 16245 & 3.66 & 22.3 & 66.0 & 23 & 10 & .32 & 800 & 3 \\
\hline 16246 & 3.85 & 23.7 & 62.8 & 25 & 15 & .59 & 600 & 10 \\
\hline 16247 & 2.86 & 29.2 & 59.7 & 30 & 249 & .71 & 550 & 10 \\
\hline 16248 & 3.51 & 3.0 & 20.7 & 5 & 5 & $<.10$ & 300 & 10 \\
\hline 16249 & 3.02 & 18.4 & 61.0 & 25 & 17 & .44 & 500 & 10 \\
\hline 16250 & 3.44 & 6.4 & 23.3 & 9 & 6 & 410 & 400 & 3 \\
\hline 16251 & 3.92 & 16.4 & 43.0 & 20 & 7 & .30 & 450 & 10 \\
\hline 16252 & 4.63 & 6.0 & 24.0 & 13 & 5 & $<.10$ & 320 & 10 \\
\hline 16253 & 3.00 & 1.2 & 24.2 & 7 & 51 & 410 & 350 & 10 \\
\hline 16254 & 2.72 & 4.1 & 15.2 & 7 & 2 & .26 & 350 & 10 \\
\hline 16255 & 2.85 & 124.9 & 19.0 & 30 & 95 & .44 & 1400 & 1.5 \\
\hline 16256 & 2.42 & 8.8 & 47.5 & 19 & 14 & $<.10$ & 450 & 10 \\
\hline 16257 & 3.66 & 4.2 & 22.6 & 6 & 5 & $<.10$ & 400 & 10 \\
\hline 16258 & 3.59 & 11.3 & 56.1 & 13 & 12 & $<10$ & 450 & 10 \\
\hline 16259 & 3.75 & 2.7 & 20.9 & 4 & 5 & $<10$ & 350 & 10 \\
\hline 16260 & 3.88 & 1.9 & 19.5 & 3 & 4 & $<.10$ & 200 & 10 \\
\hline 16261 & 1.27 & 10.8 & 52.5 & 12 & 49 & .34 & 350 & 10 \\
\hline 16262 & 4.44 & 11.3 & 64.0 & 15 & 8 & .21 & 240 & grab \\
\hline 16263 & 6.30 & 39.7 & 68.7 & 37 & 8 & $<.10$ & 240 & graí \\
\hline 16264 & 6.46 & 21.4 & 75.0 & 25 & 7 & .52 & 200 & grab \\
\hline 16265 & 1.49 & 92.3 & 18.4 & 12 & 5 & .10 & 300 & 3 \\
\hline 16871 & 1.16 & 18.4 & 8.5 & & & & 300 & 1 \\
\hline 16872 & 2.52 & 5.7 & 20.6 & & & & 140 & 10 \\
\hline 16873 & 3.48 & 5.7 & 21.6 & & & & 220 & 10 \\
\hline 16874 & 2.30 & 4.5 & 17.1 & & & & 200 & 10 \\
\hline 16875 & 1.03 & 3.9 & 9.7 & & & & 200 & 10 \\
\hline 16876 & 3.66 & 11.9 & 55.8 & & & & 360 & 3 \\
\hline 16877 & 3.94 & 18.8 & 67.8 & & & & 580 & 10 \\
\hline 16878 & 3.55 & 17.3 & 69.3 & & & & 500 & 10 \\
\hline 16879 & 4.38 & 6.1 & 30.0 & & & & 580 & 10 \\
\hline 16880 & 3.75 & 11.1 & 70.1 & & & & 260 & 10 \\
\hline 16881 & 3.44 & 3.5 & 18.2 & & & & 200 & 10 \\
\hline 16882 & 2.09 & 4.0 & 18.7 & & & & 180 & 10 \\
\hline 16883 & 4.91 & 8.5 & 34.4 & & & & 250 & 3 \\
\hline 16884 & 2.82 & 1.9 & 28.0 & & & & 200 & 3 \\
\hline 16885 & 6.79 & 16.6 & 48.6 & & & & 300 & 3 \\
\hline 16886 & 2.59 & 3.5 & 21.7 & & & & 300 & 3 \\
\hline 16887 & 3.03 & 5.0 & 21.6 & & & & 200 & 10 \\
\hline 16888 & 2.42 & 4.3 & 19.7 & & & & 160 & 10 \\
\hline 16889 & 3.19 & 5.3 & 21.0 & & & & 200 & 10 \\
\hline 16890 & 2.24 & 2.7 & 21.1 & & & & 200 & 10 \\
\hline 16891 & 2.29 & 1.5 & 12.3 & & & & 180 & 10 \\
\hline 16892 & 3.49 & 3.9 & 4.6 & & & & 250 & 10 \\
\hline 16893 & 4.17 & 9.7 & 44.8 & & & & 350 & 3 \\
\hline 16894 & 0 & 196.0 & 21.5 & & & & 800 & grab \\
\hline 16895 & 0.03 & 0.7 & 84.6 & & & & 150 & 3 \\
\hline 16896 & 5.23 & 2039.1 & 0 & & & & 5000 & 3 \\
\hline
\end{tabular}



